\title{
Potencjał procesów odnowy przedsiębiorstw - perspektywa psychologiczna
}

\section{Corporate renewal potential - a psychological perspective}

\author{
Adela Barabasz \\ Uniwersytet Ekonomicznywe Wrocławiu,e-mail: adela.barabasz@ue.pl
}

\begin{abstract}
Streszczenie
Prezentowane rozważania dotyczą wyzwań, jakie stoją przed kadrą kierowniczą przedsiębiorstw uczestniczących w procesie odnowy strategicznej. Podjęto w nim dyskusję dotyczącą zachowań, jakie powinni prezentować przedstawiciele zarządu, jeśli chcą zwiększać szanse przedsiębiorstwa na powodzenie w działaniach, których celem jest strategiczna odnowa. Artykuł ma charakter teoretyczny. Jego głównym celem jest przedstawienie zagadnień związanych z procesami strategicznej odnowy przedsiębiorstw w kontekście wyzwań, w obliczu których staje zarówno kadra zarządzająca, jak i pozostali pracownicy. Proponowane ujęcie tego zagadnienia zakotwiczone jest w psychodynamicznym podejściu do organizacji. Tematyka opracowania skoncentrowana jest na poszukiwaniu odpowiedzi na pytanie, jak wspierać pracowników przedsiębiorstw oraz jakie kompetencje powinni mieć liderzy, by z powodzeniem osiągać cele wynikające z procesu strategicznej odnowy przedsiębiorstwa.
\end{abstract}

Słowa kluczowe: odnowa strategiczna, kompetencje przywódcze, zachowania wspierające, gotowość do zmian.

\begin{abstract}
The considerations presented in the paper concern the challenges that are faced by the management of companies that are undergoing the strategic renewal process. The article discusses the behaviours which should be displayed by management representatives if they want to increase the company's chances of achieving success in the actions which are aimed at strategic renewal. The article is of theoretical nature. Its main goal is to present the issues related to the company strategic renewal processes in the context of the challenges that are faced by the management, as well as other employees. The approach to the issue proposed in the paper is anchored in the psychodynamic approach to organisation. The article focuses on seeking an answer to the question how employees of companies should be supported and what competences should the leaders have for the goals resulting from the process of company strategic renewal to be successfully achieved.
\end{abstract}

Keywords: strategic renewal, leadership competences, supporting behaviours, readiness for change. 


\section{Wstęp}

Problematyka rozwoju i zmian to jedno z najważniejszych zagadnień w obszarze nauk społecznych, $\mathrm{w}$ tym także w naukach o organizacji i zarządzaniu. Jej rozwinięciem jest zagadnienie odnowy strategicznej przedsiębiorstw. Wiąże się ono z szeroko pojmowaną problematyką zmian, szczególnie w odniesieniu do etapu przygotowania oraz jej implementacji. Złożoność i tempo zmian zachodzących w otoczeniu zewnętrznym organizacji wymagają działań wewnątrz organizacji, podążających lub uprzedzających zmiany zachodzące w otoczeniu zewnętrznym. Proces ten powinien mieć charakter permanentny i jednocześnie dynamiczny. Wzajemne, obustronne dostosowywanie wydaje się bowiem niezbędne dla przetrwania organizacji i jej rozwoju. Przedsiębiorstwa, jeśli chcą się rozwijać i odnosić sukcesy, a przynajmniej uzyskiwać satysfakcjonujące wyniki, są niejako zmuszone poprzez presję otoczenia zewnętrznego do działań optymalizujących funkcjonowanie. Sytuacja ta oznacza konieczność efektywnego odczytywania sygnałów płynących z otoczenia oraz reagowanie na nie w sposób, który daje szanse nie tylko na przetrwanie, lecz także na sukces rynkowy, jakkolwiek byłby definiowany. Następnym krokiem są działania dostosowawcze. Niejednokrotnie oznacza to konieczność gruntownych zmian $\mathrm{w}$ funkcjonowaniu przedsiębiorstwa na poziomie strategicznym, technologicznym, czasem zmian strukturalnych, a zazwyczaj odpowiednich zmian w obszarze zachowań organizacyjnych, dostosowanych do zmienionych warunków działania przedsiębiorstwa.

Mimo że na przestrzeni lat powstało wiele modeli zmian, które pomagają zrozumieć ich istotę i dynamikę, to indywidualne oraz organizacyjne wskaźniki akceptacji zmian wciąż wydają się odbiegać od poziomu, który pozwalałby sprawnie i bezboleśnie przeprowadzić organizację przez ów proces [Barabasz 2013]. Zarówno badania empiryczne, jak i studia literaturowe prowadzone w ostatnich dekadach pokazują, iż organizacje i ich liderzy nieustannie zmagają się z różnorodnymi problemami występującymi w warunkach przygotowania oraz implementacji zmian, zwłaszcza tych o charakterze strategicznym. Mimo starań menedżerów, którzy chcieliby popchnąć swoją organizację w nowym kierunku i sprawić, by lepiej odpowiadała na potrzeby klientów i sprawniej realizowała wewnątrzorganizacyjne założenia, sukces nie przychodzi ani tak łatwo, ani tak często, jak oczekują inicjatorzy zmian. Wręcz przeciwnie, wiele inicjatyw kończy się albo zupełnym niepowodzeniem, albo osiągnięciem rezultatów znacznie poniżej oczekiwań i planów, pomimo zaangażowania i wysiłków podejmowanych przez kadrę zarządzającą, a także inne kluczowe postaci w organizacji. M. Meaney i C. Pung [2008] podają, iż dwie trzecie badanych przez autorki menedżerów przyznaje, że ich firmom nie udało się przekroczyć założonego „progu zmian”, zwłaszcza w obszarze zachowań organizacyjnych. G. Probst i S. Raisch [2005] twierdzą nawet, że wdrażanie zmian bywa przyczyną poważnych kryzysów w organizacji, spowodowanych głównie nieudolnością kadry kierowniczej. Jej przedstawiciele, mimo powoływania się na określone teoretyczne koncepcje lub modele zmian, w praktyce mają bowiem duże trudności ze skutecznym ich wykorzystywaniem.

Głównym celem niniejszego opracowania jest przedstawienie zagadnień związanych z procesami strategicznej odnowy przedsiębiorstw w kontekście wyzwań, w obliczu których staje zarówno kadra zarządzająca, jak i pozostali pracownicy. Proponowane ujęcie tego zagadnienia jest zakotwiczone w psychodynamicznym podejściu do organizacji. Koncentruje się ono na relacji przełożony - podwładny, z uwzględnieniem mechanizmów i procesów regulujących zachowania jednostek, nie tylko na poziomie świadomym i werbalizowanym, lecz także na poziomie procesów leżących pod powierzchnią świadomości, często zabarwionych silnymi emocjami, zarówno nadziejami, jak i obawami, a nawet lękiem o nadchodzącą przyszłość.

Prezentowane rozważania dotyczą więc poszukiwania odpowiedzi na pytania, jak skutecznie wspierać pracowników przedsiębiorstw, które podlegają procesom odnowy o strategicznym charakterze; czy i jak wspierać proces dostrzegania szans i wyzwań, pomimo obaw, wątpliwości i zagrożeń, jakie zwykle pojawiają się, gdy naruszone jest poczucie bezpieczeństwa ukształtowanego na bazie poczucia kontroli, stałości i przewidywalności rzeczywistości organizacyjnej. W niniejszym opracowaniu przyjęto definicję, zgodnie z którą przez odnowę przedsiębiorstwa rozumie się proces, treść i efekt wymiany kluczowych elementów modelu biznesowego. Definicja ta opiera się na zaproponowanym przez G. Bełza [2012, s. 19] powiązaniu zjawiska odnowy w ujęciu R. Agarwal i C. Helfat [2009, s. 282] z diagnostyczno-projektowym ujęciem strategicznego modelowania biznesu, jakie zaproponował A. Osterwalder [Osterwalder, Pigneur 2010]. W opracowaniu podjęta została próba wskazania warunków, które, oddziałując zarówno na przedstawicieli kadry kierowniczej, jak i pracowników wykonawczych, mogą decydować o sukcesie bądź niepowodzeniu procesu odnowy o charakterze strategicznym.

\section{Istota zjawiska odnowy przedsiębiorstw}

Organizacja, jak każdy żywy organizm, tak długo, jak żyje, podlega zmianom o zróżnicowanym charakterze. Zmiany zachodzące $\mathrm{w}$ otoczeniu zewnętrznym organizacji, niezależnie od szerokości geograficznej, wielkości czy charakteru prowadzonej działalności, wymagają podejmowania działań adekwatnych do złożonego i zmiennego otoczenia. Każda organizacja, chcąc pozostawać w optymalnych relacjach $\mathrm{z}$ otoczeniem zewnętrznym, zmuszona jest więc rozwijać zdolność do szybkiego i sprawnego reagowania; nieustannie się zmieniać usprawniać i doskonalić.

Większość zmian, jakie pojawiają się w organizacji, są to zmiany nieplanowane, stopniowe, zachodzące w sposób niemal niezauważalny dla członków organizacji; zazwyczaj spełniają one kryteria zmian ewolucyjnych. Zmiany na dużą skalę, obejmujące całą organizację, przygotowywane i szczegółowo planowane, realizowane są stosunkowo rzadziej. Do tego typu zmian można zaliczyć procesy, które określa się mianem odnowy strategicznej przedsiębiorstw.

A. Agarwal i C. Helfat [2009, s. 283] piszą o dwu rodzajach procesów odnowy, czyli o strategicznej transformacji wynikającej z sytuacji nieciągłości oraz o inkrementalnej odnowie strategicznej. Wśród polskich autorów P. Banaszyk i Sz. Cyfert [2007], analizując zagadnienie strategicznej odnowy przedsiębiorstw, 
wymieniają cztery typy działań transformacyjnych i zaliczają do nich:

- dopasowanie organizacji,

- doskonalenie organizacji,

- strategiczny zwrot,

- strategiczną rewitalizację.

Sz. Cyfert, definiując pojęcie odnowy organizacyjnej, pisze, że zmiana formuły działania organizacji owocująca rekonstrukcją modelu biznesu organizacji to odnowa organizacyjna. Jednocześnie dodaje, że „...jeśli proces odnowy organizacyjnej ma być skuteczny, nie może zostać sprowadzony wyłącznie do prostego przeformułowania modelu biznesu, ale musi być rozwiązaniem systemowym, obejmującym swoim zasięgiem całą organizację" [Cyfert 2012, s. 124]. To zastrzeżenie ma istotne znaczenie w perspektywie rozważań na temat wyzwań, jakie odnowa oznacza dla kadry kierowniczej przedsiębiorstwa.

Z kolei G. Bełz i A. Krzemiński [2014] definiują strategiczną odnowę przedsiębiorstw jako „.... połączenie procesu, treści oraz efektów przebudowy lub zastąpienia tych elementów przedsiębiorstwa, które mogą znacząco wpłynąć na jego wyniki w dłuższej perspektywie i są kluczowe dla zdolności adaptacyjnych danego przedsiębiorstwa". G. Bełz [2012, s. 22] wskazuje ponadto, iż posiadanie trwałej zdolności dostosowywania się do zmieniających się warunków funkcjonowania przedsiębiorstwa zależy od wykształcenia przez organizację potencjału, określanego w literaturze mianem zdolności dynamicznych (dynamic capabilities).

Poszukiwanie czynników, które mają decydujące znaczenie w procesie kształtowania owego potencjału, to niewątpliwie wyzwanie zarówno dla zarządzających, jak i dla badaczy. Wyzwanie tym większe, że, jak pokazują definicje przytoczonych powyżej autorów, zjawisko strategicznej odnowy zaliczyć należy do tych najbardziej złożonych, a jednocześnie przedsięwzięć kluczowych dla powodzenia przedsiębiorstwa działającego w nieustannie zmieniającym się otoczeniu.

Identyfikacja czynników decydujących o powodzeniu procesu odnowy oznacza potrzebę skupienia się na ludziach, ich potrzebach, obawach, emocjach i przekonaniach. P. Barr, J. Stimpert i A. Huff [1992] podkreślają potrzebę zmiany sposobu myślenia ludzi oraz zrozumienia trudności, jakie niesie ze sobą warunek uczenia się nowego podejścia do otaczającej człowieka rzeczywistości. Warunki te są konieczne, jeśli chcemy skutecznie realizować zaplanowany proces rozwoju i odnowy przedsiębiorstwa. W tym kontekście trudno byłoby przecenić znaczenie postawy otwartości wobec świata zewnętrznego, a także potrzebę rozwijania zdolności kontenerowania napięć wynikających $\mathrm{z}$ potencjalnych rozbieżności między otoczeniem zewnętrznym a wewnętrznym światem organizacji. Znaczenie takich kompetencji, jak otwartość oraz zdolność do kontenerowania, dotyczy szczególnie przedstawicieli zarządu (kierownictwa) - liderów organizacji, którzy mają największy wpływ na to, co dzieje się w jej wnętrzu.

\section{Psychologiczne wspieranie pracowników w procesach odnowy}

Każda zmiana planowana, a zwłaszcza strategiczna odnowa przedsiębiorstwa, zgodnie z przytoczoną powyżej definicją, by mogła zakończyć się sukcesem, wymaga świadomego przywództwa. Oznacza to, że kierujący przedsiębiorstwem podzielają przekonanie, iż w zależności od rodzaju zmiany, optymalne mogą być oddziaływania innego rodzaju, powinny być stosowane innego rodzaju narzędzia oraz metody.

W kontekście niniejszego opracowania nasuwa się pytanie o narzędzia i sposoby działania, które dawałyby największe szanse na powodzenie procesów odnowy o charakterze strategicznym. Najogólniejsza odpowiedź odwołuje się do potrzeby stosowania podejścia systemowego, obejmującego całą organizację, w różnych jej wymiarach i na różnych szczeblach struktury hierarchicznej. Z perspektywy psychologicznej warto odwołać się do propozycji wspierania procesów zmian, jaką przedstawił W.W. Burke [2006, s. 111]. Autor ten wskazuje na trzy główne podejścia i wynikające z nich zadania, jakie mają do zrealizowania przedstawiciele kadry kierowniczej. Każde z tych podejść ma na celu wspieranie członków organizacji w radzeniu sobie z konsekwencjami uczestnictwa w złożonym i jedynie częściowo przewidywalnym procesie zmian, jakie wynikają z założeń o potrzebie odnowy o charakterze strategicznym.

Głównym zadaniem kierownictwa, zgodnie z pierwszym podejściem, jest konceptualizacja złożonego procesu odnowy (i jakiejkolwiek zmiany). Kluczowym aspektem drugiego podejścia jest koncentracja na domykaniu spraw wcześniej rozpoczętych. Podstawowe zadanie w trzecim podejściu opiera się na stwarzaniu warunków do partycypacji pracowników w procesie przygotowania i implementacji procesów odnowy.

Bez wątpienia przedstawienie ludziom sposobu rozumienia zjawisk i procesów, w których uczestniczą, oraz nazwanie reakcji, których doświadczają, jest niezwykle pomocne. Wykorzystuje się tego typu podejście z powodzeniem w innych, różnorodnych i złożonych procesach oraz aktywnościach, przede wszystkim w procesie edukacji oraz psychoterapii. Chociaż w innych warunkach i na inną skalę, procesy te opierają się na tym samym mechanizmie, który odwołuje się do poczucia sprawstwa, kontroli i wpływu na otoczenie W. Bridgesa [1986]. Autor ten dokonał istotnego rozróżnienia między zmianą a transformacją, wskazując, że transformacja jest procesem psychologicznym, rozciągniętym w czasie; ponadto proces transformacji nie może być kierowany w sposób tylko racjonalny, bez uwzględnienia emocji i wewnętrznego świata przeżyć każdego członka organizacji. Natomiast w przeciwieństwie do procesu transformacji, procesem zmiany można kierować w sposób racjonalny. To racjonalne kierowanie zmianą jest podstawowym zadaniem menedżerów, którzy odpowiadają za całokształt funkcjonowania organizacji [Bridges 1986]. Powyższa konceptualizacja istotnie ułatwia postępowanie w procesie kierowania zmianami. Pozwala w sposób celowy i świadomy skutecznie dobierać narzędzia i środki oddziaływania, dostosowując je do potrzeb konkretnej sytuacji, z uwzględnieniem właściwości adresatów podejmowanych oddziaływań (jednostek, grup i całej organizacji). 
Według W.W. Burke [2006, s. 112] ważna jest także świadomość psychologicznego znaczenia warunków, w których członkowie organizacji mają wykonywać nowe zadania, często nieoczekiwanie przerywając realizację dotychczasowych zadań bądź funkcji. Z taką sytuacją członkowie organizacji w procesie odnowy konfrontują się dość powszechnie. Jedną z psychologicznych konsekwencji takiego stanu rzeczy jest tzw. efekt Zeigarnik. Oznacza on napięcie, gdy realizowane przez jednostkę zadanie (lub jakakolwiek inna aktywność) zostaje przerwane z dowolnych przyczyn. W efekcie działanie pozostaje nieukończone - usunąć owo napięcie może jego dokończenie. W sytuacji szeroko rozumianych zmian organizacyjnych, także w warunkach strategicznej odnowy, można obserwować występowanie mniej lub bardziej intensywnego dążenia do prezentowania przez pracowników postaw i zachowań ukierunkowanych na kontynuację „starych”, przerwanych zadań. Dzieje się tak niekoniecznie tylko i wyłącznie z powodu potrzeby powracania do wypracowanego nawyku. Takie zachowania często bywają mylnie rozumiane jako opór wobec zmian. Tymczasem warto wziąć pod uwagę inną interpretację, zgodnie z którą członkowie organizacji usiłują domknąć sprawy i osiągnąć cele, które pozostają niezakończone, a będąc takimi w świadomości pracowników, domagają się domknięcia. W przeciwnym razie staną się źródłem dyskomfortu i napięcia, często trudnego do zdefiniowania przez doświadczających go pracowników. W tym kontekście, uwzględniając perspektywę psychologiczną, pracownicy zachowują się „racjonalnie”, mimo że motywacja do działania ma charakter emocjonalny (jego źródłem jest odczuwane napięcie). Często towarzyszy temu mniej lub bardziej przekonująca racjonalizacja, czyli usprawiedliwianie i rozumowe wyjaśnianie podejmowanych działań. Rozróżnianie rzeczywistego oporu wobec zmian oraz zachowań, które uruchamiane są przez zupełnie inny mechanizm psychologiczny, jakim jest potrzeba zamykania spraw niedokończonych, jest jedną z oznak kompetencji przywódców w procesie zarządzania zmianami.

Trzecie podejście wskazywane przez W.W. Burke [2006] jako sposób wspierania pracowników w procesach zmian, w tym także $\mathrm{w}$ procesie odnowy strategicznej, to partycypacja. Na partycypację jako czynnik redukujący opór wobec zmian oraz istotnie zwiększający zaangażowanie i identyfikację pracowników z celami zmian zwracają uwagę liczni autorzy od wielu lat (zob. [Clark 1997; Kotter 1996; Burnes 2004; Burke 2006]). Wydaje się nawet, że założenie o partycypacji pracowników w procesie przygotowania i implementacji zmian traktowane jest jako oczywiste; partycypacja bywa więc opisywana jako decydująca o sukcesie we wdrożeniu zmian. W rzeczywistości jednak często jest to bardziej deklaracja aniżeli realizowany sposób podejmowania decyzji dotyczących celów i kierunków zmian, w tym także tych o charakterze strategicznym. Pozostaje pytanie o przyczyny takiego stanu rzeczy.

\section{Przywództwo w procesie strategicznej odnowy - ujęcie psychodynamiczne}

O sposobie funkcjonowania organizacji decyduje wiele czynników, które mogą odgrywać istotną rolę w kształtowaniu jej mechanizmów adaptacyjnych na różnych etapach rozwoju. Suk- ces zależy od dopasowania poszczególnych elementów, tworzących jej wnętrze, do otoczenia zewnętrznego. Sytuację komplikuje fakt, iż owo otoczenie nieustannie się zmienia. Niezbędne staje się więc rozwijanie takich zdolności adaptacyjnych, które zapewnią sprawne reagowanie na zmienność otoczenia, będą podtrzymywać ciągłość funkcjonowania organizacji, a w efekcie sprzyjać sukcesowi ekonomicznemu firmy.

Znaczenie przywództwa w procesie zmian organizacyjnych przyciąga uwagę zarówno teoretyków, jak i praktyków zarządzania, którzy zgodnie wskazują na potrzebę świadomego i celowego kształtowania efektywnego przywództwa. Konfrontacja kadry zarządzającej z potrzebą implementacji zmian w organizacji to swego rodzaju sprawdzian kompetencji osób zarządzających organizacją. Efektywne przywództwo to także kluczowy czynnik w procesie odnowy strategicznej, rozumianej jako rekonstrukcja modelu biznesu, zwłaszcza jeśli ma to być działanie o charakterze systemowym, obejmującym całą organizację, jak podkreślają cytowani wcześniej autorzy (zob. [Bełz, Cyfert, Wawrzynek 2014; Cyfert 2012; Bełz, Krzemiński 2014; Bełz 2011]).

Podstawowe funkcje przywództwa w procesie odnowy to m.in. działania na rzecz dopasowywania czynników wewnętrznych i zewnętrznych wobec organizacji, które stały się bodźcem do podjęcia decyzji o „rekonstrukcji modelu biznesu”. Zadaniem kadry kierowniczej jest więc wyważenie znaczenia i wpływu otoczenia na zmianę wewnątrz organizacji oraz skonfrontowanie tych czynników z potrzebą zmian wewnątrz organizacji. Silne przekonanie o potrzebie zmian (a w tym przypadku przeprowadzenia procesów odnowy) wewnątrz organizacji zwiększa prawdopodobieństwo uniknięcia istotnych problemów, jakie wynikają z oporu wobec zmian.

Perspektywa psychodynamiczna zwraca uwagę na obserwację zachowań kluczowych członków organizacji i pozwala na rozpoznawanie powtarzających się wśród nich schematów zachowań. Schematy te są nośnikami informacji o tym, w jaki sposób osoby kluczowe, a poprzez nie także cała organizacja, radzą sobie z lękiem, poczuciem zagrożenia, niepewnością, ryzykiem, potrzebą rozwoju versus pragnienie stałości i bezpieczeństwa. Te stany emocjonalne są istotne dla każdej zmiany organizacyjnej z powodu ich uniwersalnego charakteru, czyli częstotliwości i powszechności występowania. Doświadczane są na poziomie jednostek, grup i całych organizacji, a szczególnie wyraźnie widać owe adaptacyjne bądź dezadaptacyjne wzorce zachowań wtedy, gdy pojawiają się jakiekolwiek trudności i zakłócenia w standardowym i rutynowym działaniu.

M.F. Kets de Vries [2006], reprezentujący psychodynamiczne podejście do przywództwa, podkreśla, iż jego istotą jest osobowość oraz zachowania liderów; zwłaszcza te, które utrwalają i podtrzymują psychologiczny kontrakt dotyczący wzajemnych oczekiwań w relacjach przełożony - podwładni. Samoświadomość, w tym świadomość doświadczanych emocji, rozumienie relacji intrapsychicznych, interpsychicznych, wewnątrzgrupowych i międzyorganizacyjnych, to podstawowe zagadnienia, które wydają się najistotniejsze z perspektywy psychologicznego spojrzenia na przywództwo. 0 ile bowiem obiektywne czynniki i wymierne dane odgrywają istotną rolę w kształto- 
waniu działań wolicjonalnych oraz $\mathrm{w}$ procesie podejmowanych przez przywódców decyzji, o tyle to właśnie osobowość i doświadczenie mają zasadniczy wpływ na strategiczne wybory i zachowania wewnątrzorganizacyjne [Finkelstein, Hambrick 1990, s. 489-500; Chatterjee, Hambrick 2007, s. 351-386].

Kierowanie ludźmi nie odbywa się ani w próżni, ani w izolacji, lecz, jak inne aktywności człowieka, zachodzi w określonym kontekście społecznym, politycznym, ekonomicznym czy geograficznym. Istotą przywództwa jest jednak relacja - dokonuje się ono bowiem zawsze $\mathrm{w}$ kontakcie między przełożonym a podwładnym, w określonych warunkach, jakie stwarza organizacja. Kształtuje ona ramy, które wyodrębniają ją z otoczenia - nadają strukturę, wyznaczają kierunek, ustalają zasady, normy i wartości. W tak zorganizowanej przestrzeni realizuje się relacja przywództwa. Takie rozumienie przywództwa określa się mianem przywództwa interakcyjnego [Kets de Vries 2006], zgodnie z którym nie tylko osobowość, pozycja i doświadczenia lidera odgrywają istotną rolę; znaczenie ma także osobowość podwładnych (ich system wartości, postawy, zdolność do współpracy w grupie) oraz cechy wynikające z sytuacji (charakter zadania, typ organizacji, kultura organizacyjna, czynniki gospodarcze, jak branża, czynniki socjoekonomiczne, a także polityczne).

Zgodnie z psychodynamicznym podejściem do organizacji, każdy jej członek przystosowuje się, ale też współtworzy określony styl przywództwa i rozwija określone kompetencje, które wynikają z jego „wewnętrznego skryptu”, zbudowanego na wewnętrznych potrzebach, konfliktach, pragnieniach, lękach, wyobrażeniach o sobie, świecie, o autorytetach, o tym, co dobre, a co złe (zob. [Gabriel 2004; Stapley 1996]).

Model przywództwa transformacyjnego, zaproponowany przez B.M. Bassa, B. Avolio i L. Atwater [1996], jest jednym z pierwszych, który pokazuje wpływ zachowań lidera na zachowanie podwładnych. Natomiast prace M. Higgsa oraz D. Rowland [2000; 2005] pokazują bezpośredni związek między zachowaniami przywódców a aktywnością osób zaangażowanych w zmiany. Autorzy ci zidentyfikowali pięć obszarów kompetencji przywódczych, które korelują z sukcesem w procesie implementacji zmian. Są to:

1. Aktywne działanie na rzecz angażowania innych członków organizacji w rozpoznawanie i kształtowanie biznesowej świadomości potrzeby zmian.

2. Kształtowanie bazy strukturalnej poprzez zapewnianie członków organizacji, że kadra zarządzająca nie tylko ma głębokie przekonanie o potrzebie zmian, ale też będzie je wspierać i dostarczać niezbędnych środków oraz narzędzi do jej implementacji.

3. Kształtowanie zaangażowania wszystkich członków organizacji w proces zmian.

4. Implementacja i podtrzymywanie zmian - planowanie, monitorowanie i systematyczne sprawdzanie efektów wprowadzanych nowych praktyk.

5. Wspieranie potencjału tkwiącego w ludziach - budowanie przekonania i emocjonalnego poczucia bezpieczeństwa; odwoływanie się do przeświadczenia, że pracownicy potrafią znajdować własne rozwiązania problemów, ale też wspieranie ich poszukiwań, niekaranie za ewentualne błędy.
M. Higgs i D. Rowland w dalszych badaniach wyodrębnili trzy kategorie zachowań podejmowanych przez menedżerów w sytuacji zmian. Są to [Higgs, Rowland 2011, s. 312]:

1. Zachowania kształtujące (shaping behavior), które wyrażają się w komunikowaniu się i zachowaniach powiązanych bezpośrednio ze zmianami, takich jak: „czynienie innych odpowiedzialnymi”, „myślenie o zmianie”, „odwoływanie się do indywidualnej sytuacji pracownika".

2. Nadawanie struktury (framing): określenie momentu startu; „zaplanowanie i kierowanie podróżą, jaką jest zmiana”, „informowanie o głównych zasadach, wartościach w organizacji".

3. Kreowanie (creating capabilities) potencjału pracowników (czyli zdolności, umiejętności, kompetencji): kreowanie indywidualnych i organizacyjnych umiejętności, komunikowanie się i budowanie więzi pomiędzy członkami organizacji.

W świetle badań tychże autorów [Higgs, Rowland 2011, s. 312] kształtowanie zachowań (shaping behavior) koreluje z cechami liderów egocentrycznych, natomiast strukturowanie (framing) i kreowanie możliwości (creating capabilities) koreluje z zachowaniami służącymi powodzeniu zmiany. M. Higgs i D. Rowland [2011, s. 309--335], konkludując, piszą, że menedżerowie wspierający, ułatwiający i zaangażowani w zmianę zwiększają prawdopodobieństwo powodzenia w procesie implementacji, menedżerowie zaś skupieni na sobie (egocentryczni) są zdecydowanie mniej skuteczni we wprowadzaniu zmian.

Z kolei W.W. Burke [2011, s. 271-272], dla zapewnienia powodzenia $\mathrm{w}$ procesie szeroko rozumianych zmian, wskazuje na konieczność posiadania przez przełożonych takich kompetencji jak:

- tolerancja wieloznaczności;

- radzenie sobie z potrzebą kontroli - menedżer powinien mieć jasność co do tego, co jest w stanie skontrolować, a co pozostaje poza jego kontrolą;

- rozumienie wpływu emocji na zachowania - zwłaszcza w trudnych sytuacjach, ułatwia rozumienie zachowania podwładnych;

- $\quad$ świadomość osobistych predyspozycji - pomocne bywają psychologiczne diagnozy za pomocą takich narzędzi, jak MBTI (Myers Briggs Type Indicator);

- decyzyjność - ważny jest wybór sposobu podjęcia decyzji, czyli ocena, kiedy podjąć decyzję jednoosobowo, a kiedy i kogo włączyć w proces decyzyjny.

Powyższe badania ujawniają wagę właściwości, którą najtrafniej opisuje pojęcie gotowości do zmian. Według B. Weinera [2009, s. 68] gotowość do zmian jest to zaangażowanie członków organizacji w zmianę organizacyjną, co ma prowadzić do jej skutecznej implementacji.

A. Rafferty, N. Jimmieson i A. Armenakis [2013, s. 110-135] wyodrębniają dwie grupy czynników, które decydują o poziomie gotowości do zmian. Są to czynniki poznawcze oraz czynniki emocjonalne. Wśród czynników określonych jako poznawcze wskazują na (1) przekonanie o konieczności zmian oraz (2) przeświadczenie, że ludzie i organizacja są w stanie podjąć wy- 
zwanie, jakim jest zmiana [Armenakis, Harris, Mossholder 1993].

Natomiast A.A. Armenakis i S.G. Harris [2002] wyróżnili pięć charakterystycznych przekonań, które leżą u podstaw gotowości do zmiany definiowanej na poziomie jednostki. Są to:

- przekonanie, że zmiana jest konieczna - przesłanki dotyczące zmiany powinny kreować poczucie rozbieżności, dyskomfortu wynikającego z oceny stanu aktualnego i porównania z tym, jaki chcielibyśmy, by był; ten element dość powszechnie podkreślają autorzy wielu koncepcji i modeli zmian, poczynając od modelu Kurta Lewina;

- jednostka musi być przekonana, że proponowana zmiana jest właściwą reakcją w danej sytuacji;

- jednostka powinna mieć poczucie wpływu i własnej skuteczności, czyli widzieć możliwości wdrożenia zmian;

- jednostka musi być przekonana, że ze strony organizacji otrzyma konkretne wsparcie poprzez udostępnienie posiadanych zasobów i informacji;

- jednostka dokonuje indywidualnej, prywatnej oceny potencjalnych zysków i strat związanych ze swoją rolą w procesie zmian $\mathrm{w}$ organizacji; jeśli nie wierzy, że zmiana wniesie cokolwiek pozytywnego $\mathrm{w}$ jej życie, nie będzie skłonna być otwartą na zmianę.

A.E. Rafferty, N.L. Jimmieson i A.A. Armenakis [2013, s. 113-114] podkreślają, że na gotowość do zmian jednostki wpływają indywidualne przekonania (jak wyżej) oraz jej aktualne, pozytywne emocjonalnie nastawienie wobec przyszłości. Emocjonalne czynniki gotowości do zmiany V.D. Miller, J.R. Johnson i J.G. Grau [1994, s. 60] definiują jako te, które wyrażają pozytywne emocje wobec pozytywnych konsekwencji zmian.

Rola przywódców w kształtowaniu gotowości do zmian, zwłaszcza na poziomie poznawczym, jest decydująca, na poziomie emocjonalnym tym większa, im silniejsze więzi emocjonalne łączą podwładnych z przełożonymi, przy czym charakter tych więzi w znacznym stopniu pozostaje poza świadomą refleksją większości członków organizacji. Tym większa więc rola i zakres możliwości kształtowania poznawczej gotowości do zmian na poziomie świadomej dyskusji o celach, kierunkach, zyskach i stratach, a także emocjonalnych kosztach uczestniczenia $\mathrm{w}$ procesach strategicznej odnowy przedsiębiorstwa.

Szanse na powodzenie w procesach odnowy strategicznej są tym większe, im bardziej członkowie organizacji, przede wszystkim jej liderzy, mają świadomość złożoności oraz reaktywności, czyli wzajemnego oddziaływania i obustronnej wymiany. Zachodzi ona nieustannie pomiędzy przywódcami a podwładnymi w ramach struktury organizacyjnej, lecz nabiera szczególnego znaczenia, gdy do głosu dochodzą emocje, zwłaszcza negatywne, związane z lękiem przed nową sytuacją. Jeśli wziąć pod uwagę interakcyjność relacji przywódca - podwładni, nie do przecenienia jest zaufanie podwładnych do przełożonego (przywódcy). Niezależnie więc od tego, jak złożone i wyczerpujące są koncepcje dotyczące kompetencji przywódców, jeśli zgadzamy się, że przywództwo ma charakter interakcyjny, kwestią zasadniczą pozostaje wzajemne zaufanie między przełożonym a przywódcą. Zaufanie oznacza zaś wiarę podwładnego, iż przełożony jest otwarty, uczciwy i mówi prawdę, czyli mówi to, w co rzeczywiście wierzy, a jego słowa pokrywają się z czynami. Przekłada się to bezpośrednio na gotowość do zaangażowania się w proces zmian.

\section{Podsumowanie}

Wyzwaniem dla liderów jest rozwijanie szerokiego repertuaru cech i zachowań, ogólnie nazywanych kompetencjami, które odpowiadają na zróżnicowane potrzeby otoczenia wewnętrznego organizacji, a także na zapotrzebowanie wynikające z wymagań otoczenia zewnętrznego. Dla powodzenia w każdym procesie zmian, a więc także, a może nawet szczególnie, w procesach strategicznej odnowy, niezbędni są liderzy świadomi roli, jaką mają do odegrania w tym złożonym procesie. W dobie powszechności zmian, często o niespotykanej wcześniej dynamice, która wynika z postępu dokonującego się za sprawą rozwoju nowoczesnych technologii, trudno być dobrym przywódcą, zwłaszcza bez tej psychologicznej kompetencji, którą określa się jako „orientacja na zmiany” bądź „gotowość do zmian".

Przedstawione powyżej zagadnienia mają na celu zwrócenie uwagi na relację przełożony - podwładni w procesie odnowy strategicznej przedsiębiorstwa. Choć teza, zgodnie z którą relacja ta ma istotny wpływ na przebieg procesu odnowy i jej ostateczny wynik, jest dość oczywista, to znacznie mniej oczywiste są zależności między kompetencjami przywódców (cechy, zachowania), ich oddziaływaniem na podwładnych (wzajemne relacje) a powodzeniem w procesach odnowy (zmiany). Celem rozważań jest zwrócenie uwagi na te zachowania liderów (kierowników, menedżerów), które zwiększają prawdopodobieństwo powodzenia w procesach odnowy. Do nich należy z jednej strony nadawanie kierunku zmianom oraz ich nieustanne monitorowanie, a z drugiej - kontakt z podwładnymi w celu wydobywania i kształtowania tkwiącego w nich potencjału.

\section{Literatura}

Agarwal R., Helfat C., 2009, Strategic renewal of organizations, Organization Science, vol. 20, no 2, s. 281-293.

Armenakis A.A., Harris S.G., 2002, Crafting a change message to create transformational readiness, Journal of Organizational Change Management, vol. 15, s. 169-183.

Armenakis A.A., Harris S.G., Mossholder K.W., 1993, Creating readiness for organizational change, Human Relations, vol. 46, s. 681-703.

Banaszyk P., Cyfert Sz., 2007, Strategiczna odnowa przedsiębiorstw, Difin, Warszawa.

Barabasz A., 2013, Osobowość przywódcy i organizacji jako czynnik powodzenia w procesie zmian, [w:] Uwarunkowania sukcesu organizacji, red. H. Czubasiewicz, Z. Mokwa, P. Walentynowicz, Fundacja Rozwoju Uniwersytetu Gdańskiego, Gdańsk.

Barr P., Stimpert J., Huff A., 1992, Cognitive change, strategic action, and organizational renewal, Strategic Management Journal, vol. 13, s. $15-36$.

Bass B.M, Avolio B., Atwater A., 1996, The transformational and transactional leadership of men and women, Applied Psychology, vol. 45, iss. 1 (January), s. 5-34. 
Bełz G., 2012, Potencjał dostosowawczy w procesach odnowy przedsiębiorstw, Przegląd Organizacji, nr 11, s. 19-22.

Bełz G., 2011, System zarzq̨dzania jako regulator odnowy $i$ wzrostu przedsiębiorstw, Prace Naukowe UE we Wrocławiu, nr 153, Wrocław.

Bełz G., Cyfert Sz., Wawrzynek Ł., 2014, Wpływ burzliwości otoczenia na efektywność procesów odnowy organizacyjnej, Organizacja i Kierowanie, 1A (159), s. 15-25.

Bełz G., Krzemiński A., 2014, Zarządcze struktury sieciowe w procesie odnowy przedsiębiorstw, Marketing i Rynek, nr 5.

Bridges W., 1986, Managing organizational transitions, Organizational Dynamics, vol. 15, no 1, s. 24-33.

Burke W.W., 2006, Organizations Change. Theory and Practice, Sage Publications, Thousand Oaks (California).

Burnes B., 2004, Managing Change: A Strategic Approach to Organizational Dynamics, Financial Times Prentice Hall, Harlow.

Chatterjee A., Hambrick D.C., 2007, It's all about me: Narcissistic chief executive officers and their effects on company strategy and performance, Administrative Science Quarterly, vol. 52, s. 351-386.

Clark L., 1997, Zarządzanie zmianq, Gebethner i S-ka, Warszawa.

Cyfert Sz., 2012, Systemowy model organizacji: perspektywa procesów odnowy organizacyjnej, Prace Naukowe UE we Wrocławiu, nr 276, Wrocław, s. 123-129.

Finkelstein S., Hambrick D.C., 1990, Top management tenure and organizational outcomes: The moderating role of managerial discretion, Administrative Science Quarterly, vol. 35, s. 484-500.

Gabriel Y., 2004, Organizations in Depth, Sage Publications, London 2004.
Higgs M., Rowland D., 2005, All changes great and small: Exploring approaches to change and its leadership, Journal of Change Management, no 5, s. 121-151.

Higgs M., Rowland D., 2000, Building change leadership capability: The quest for change competence, Journal of Change Management, no 1 , s. 116-130.

Higgs M., Rowland D., 2011, What does it take to implement change successfully? A study of the behaviors of successful change leader, The Journal of Applied Behavioral Science, vol. 47, no 3, s. 309-335.

Kets de Vries M.F., 2006, The Leadership Mystique, Prentice Hall, Edinburgh.

Kotter J.P., 1996, Leading Change, Harvard Business School Press, Boston.

Meaney M., Pung C., 2008, McKinsey global results: Creating organizational transformations, McKinsey Quarterly, August, s. 1-7.

Miller V.D., Johnson J. R., Grau J.G., 1994, Antecedents to willingness to participate in a planned organizational change, Journal of Applied Communication Research, vol. 22, s. 59-80.

Osterwalder A., Pigneur Y., 2010, Business Model Generation, John Wiley \& Sons, Hoboken

Probst G., Raisch S., 2005, Organizational crisis: The logic of failure, Academy of Management Review, vol. 19, s. 90-105.

Rafferty A.E., Jimmieson N.L., Armenakis A.A., 2013, Change readiness: A multilevel review, Journal of Management, vol. 39, no 1 (January), s. 110-135.

Stapley L., 1996, The Personality of the Organization: A Psycho-dynamic explanation of culture and change, Free Association Books, London.

Weiner B., 2009, A Theory of organizational readiness for change, Implementation Science, no 4, s. 67-75. 